\title{
Burkholderia tropica sp. nov., a novel nitrogen-fixing, plant-associated bacterium
}

\section{Correspondence \\ J. Caballero-Mellado jesuscab@cifn.unam.mx}

\author{
V. M. Reis, ${ }^{1} \dagger$ P. Estrada-de los Santos,${ }^{2} \dagger$ S. Tenorio-Salgado, ${ }^{2}$ J. Vogel, ${ }^{3}$ \\ M. Stoffels, ${ }^{4}$ S. Guyon, ${ }^{5}$ P. Mavingui, ${ }^{2,5}$ V. L. D. Baldani, ${ }^{1}$ M. Schmid, ${ }^{4}$ \\ J. I. Baldani, ${ }^{1}$ J. Balandreau, ${ }^{3,5}$ A. Hartmann ${ }^{4}$ and J. Caballero-Mellado ${ }^{2}$

\begin{abstract}
${ }^{1}$ Centro Nacional de Pesquisa de Agrobiologia (EMBRAPA-Agrobiologia), km 47, Seropédica,
\end{abstract} \\ 23851-970, CP 74505, Rio de Janeiro, Brazil \\ ${ }^{2}$ Centro de Investigación sobre Fijación de Nitrógeno, Universidad Nacional Autónoma de \\ México, Ap. Postal 565-A, Cuernavaca, Morelos, México \\ ${ }^{3}$ SASA Experiment Station, Private Bag X02, Mt Edgecombe, KZN, 4300 South Africa \\ ${ }^{4}$ GSF - National Research Center for Environment and Health, Institute of Soil Ecology, \\ Department of Rhizosphere Biology, Ingolstädter Landstr.1, D-85764 Neuherberg/Munich, \\ Germany \\ ${ }^{5}$ Ecologie Microbienne, UMR CNRS 5557 Université Claude Bernard Lyon I, 43 Bd du \\ 11 Novembre 1918, 69622 Villeurbanne cedex, France
}

\section{INTRODUCTION}

Thirty different Burkholderia species have been described so far (Coenye \& Vandamme, 2003). For a long time, $\mathrm{N}_{2}$-fixing ability in bacteria of the genus Burkholderia was recognized only in the species Burkholderia vietnamiensis (Gillis et al., 1995). This species was isolated from the rhizosphere of young rice plants grown on a Vietnamese soil under

\footnotetext{
Abbreviation: ARDRA, amplified 16S rDNA restriction analysis.

The GenBank/EMBL/DDBJ accession number for the 16S rRNA gene sequences of the Burkholderia tropica strains determined in this work are AJ420332, AY128103, AY321306, AY128105 and AY128104.

TV. M. Reis and P. Estrada-de los Santos contributed equally to this study.

Detailed Biolog results, ARDRA profiles and an extended 16S rRNA gene-based phylogenetic tree are available as supplementary material in IJSEM Online.
}

laboratory conditions (Trân Van et al., 1994). Concomitant with the creation of the genus Burkholderia in the early 1990s, diazotrophic bacteria were obtained in a survey of root-associated diazotrophs in sugarcane grown in Brazil, and the first indication of their affiliation to the genus Burkholderia was gained from partial 23S rRNA gene sequences (Hartmann et al., 1995). On the basis of the $23 \mathrm{~S}$ rRNA gene sequence data, an oligonucleotide probe (PPe8) was developed, which was characteristic of these isolates (Kirchhof et al., 1997). Among diazotrophic isolates obtained from the banana and pineapple rhizosphere in Brazil, several grouped within the genus Burkholderia using $23 \mathrm{~S}$ rRNA gene oligonucleotide probing and phenotypic techniques (Weber et al., 1999). Two isolates from pineapple showed an amplified 16S rDNA restriction analysis (ARDRA) pattern identical to the sugarcane isolate $\mathrm{Ppe} 8^{\mathrm{T}}$ (Cruz et al., 2001). Recently, the analysis of $\mathrm{N}_{2}$-fixing bacteria associated with maize and coffee plants grown under 
field conditions revealed the presence of B. vietnamiensis, as well as the richness of novel diazotrophic bacterial species belonging to the genus Burkholderia (Estrada-de los Santos et al., 2001; Estrada et al., 2002). These $\mathrm{N}_{2}$-fixing isolates exhibited high diversity in the ARDRA profiles. In addition, two nodulating strains recovered from legume plants were recently assigned to the genus Burkholderia according to their 16S rRNA gene sequences (Moulin et al., 2001). These strains have been formally described as Burkholderia tuberum and Burkholderia phymatum (Vandamme et al., 2002).

In this study, a polyphasic approach was undertaken to determine the taxonomic status of bacterial isolates recovered from sugarcane, maize and teosinte plants grown in different geographical and climatic regions of Brazil, Mexico and South Africa. The analysis revealed that these isolates belong to a novel species within the genus Burkholderia, for which the name Burkholderia tropica sp. nov. is proposed.

\section{METHODS}

Isolation and cultivation of diazotrophic bacterial strains. The sources of the 41 Burkholderia isolates analysed are shown in Table 1. $\mathrm{N}_{2}$-fixing Burkholderia isolates were recovered using three different strategies. In Mexico, the diazotrophic isolates were recovered from the rhizosphere, rhizoplane and inner tissues of maize and teosinte plants using the nitrogen-free semi-solid BAz medium and BAc agar plates as described previously (Estrada-de los Santos et al., 2001). In Brazil, diazotrophic bacteria were isolated from sugarcane in nitrogen-free semi-solid LGI-P medium containing cane juice (Reis et al., 1994). Stems and roots of the sugarcane plants were washed and then macerated and aliquots were inoculated into vials containing semi-solid LGI-P medium. After incubation for $4-5$ days at $30^{\circ} \mathrm{C}$, a fine subsurface pellicle was formed. The contents of vials showing pellicles were transferred to semi-solid JMV medium with the following composition $\left(\mathrm{g} \mathrm{l}^{-1}\right)$ : $5 \cdot 0$ mannitol, $0.6 \mathrm{~K}_{2} \mathrm{HPO}_{4}, \quad 1.8 \mathrm{KH}_{2} \mathrm{PO}_{4}, 0.2 \quad \mathrm{MgSO}_{4} .7 \mathrm{H}_{2} \mathrm{O}, 0 \cdot 1 \mathrm{NaCl}, 0.02$, $\mathrm{CaCl}_{2} \cdot 2 \mathrm{H}_{2} \mathrm{O}, 0 \cdot 05$ yeast extract, 1.6 agar, adjusted to $\mathrm{pH} 5 \cdot 5-5 \cdot 7$. New growth was streaked out on JMV or LGI-P solid medium supplemented with yeast extract $\left(100 \mathrm{mg} \mathrm{l}^{-1}\right)$. Grown colonies were inoculated into fresh semi-solid JMV medium and finally transferred to LGI-P solid medium for characterization. Burkholderia strains recovered in South Africa were isolated from the roots of sugarcane. Roots were washed gently with tap water and then blended and aliquots were plated onto PCAT medium (Burbage \& Sasser, 1982). After incubation for $48 \mathrm{~h}$, bacterial colonies were transferred to PCAT agar plates once more and purified on tryptic soy agar plates.

Phenotypic characterization. Strains were grown at $29^{\circ} \mathrm{C}$ unless otherwise indicated. The presence of capsules was determined microscopically by the presence of white haloes surrounding the bacteria suspended in black ink dye (Black ink; Hering ref. 12250). To determine other phenotypic features, cells were prepared by growing the isolates for $12 \mathrm{~h}$ in BSE medium (Estrada-de los Santos et al., 2001). Cultures were washed twice in $10 \mathrm{mM} \mathrm{MgSO}_{4}$, adjusted to an OD of $0 \cdot 2\left(3 \times 10^{6}\right.$ c.f.u. $\left.\mathrm{ml}^{-1}\right)$ and each culture was streaked onto solid media. The effects of temperature and $\mathrm{pH}$ on growth were determined in BSE agar medium. The effects of temperature and $\mathrm{pH}$ on growth and nitrogenase activity of some strains (Ppe5, Ppe6, Ppe7 and $\mathrm{Ppe}^{\mathrm{T}}$ ) were also evaluated in a nitrogen-free semi-solid JMV medium. The optimal growth temperature was determined indirectly by measuring nitrogenase activity by the acetylene reduction method (Burris, 1972). Growth on MacConkey agar (Difco) plates as well as on BCSA medium (Henry et al., 1997) was determined after $72 \mathrm{~h}$ at 29 and $37^{\circ} \mathrm{C}$. Tests such as oxidase, catalase and hydrolysis of gelatin and Tween 80 were performed by the methods of Smibert \& Krieg (1981). Strains were analysed with the API 20NE, API 50CH (bioMérieux) and Biolog MicroLog systems. In the case of API $20 \mathrm{NE}$ and API $50 \mathrm{CH}$ tests, the inoculation was performed according to the recommendations of the manufacturer (bioMérieux). The results for API 20NE were obtained after 24 or $48 \mathrm{~h}$ of incubation as recommended by the manufacturer and API 50CH galleries were obtained after 6 days of incubation. When the Biolog system was used, strains were incubated on biological universal growth medium (Biolog) at $30^{\circ} \mathrm{C}$ for $24 \mathrm{~h}$. GN2 microplates were inoculated according to the manufacturer's instructions and incubated at $30^{\circ} \mathrm{C}$ for $24 \mathrm{~h}$. The quantitative data of carbon source utilization by each strain were transformed to categories using the CategVar module in ADE-4 software (Biolog).

SDS-PAGE of whole-cell proteins and siderophore production. Preparation of whole-cell proteins as well as SDS-PAGE assays were performed as described previously (Estrada-de los Santos et al., 2001). Siderophores were detected using the universal chemical assays on chromeazurol-S agar plates and in chromeazurol-S solution as described previously (Schwyn \& Neilands, 1987). Hydroxamate-type siderophores were identified using the test of Czàky (1948).

ARDRA and sequencing. Genomic DNA was isolated from bacterial cells using published protocols (Kirchhof et al., 1997; Ausubel et al., 1987). Primers $\mathrm{fD} 1$ and $\mathrm{rD} 1$ were used for amplification of the 16S rRNA gene (Weisburg et al., 1991) using PCR conditions described previously (Estrada-de los Santos et al., 2001). The amplified $16 \mathrm{~S}$ rRNA genes were restricted with AluI, DdeI, HaeIII, HhaI, HinfI, MspI and RsaI. The restriction fragments were separated by electrophoresis in $3 \%$ agarose gels and the patterns were compared. Each isolate was assigned to one of the ARDRA genotypes 16, 17 or 19 as described previously (Estrada-de los Santos et al., 2001). For the strain $P$ pe ${ }^{\mathrm{T}}$, an almost full-length bacterial $16 \mathrm{~S}$ rRNA gene fragment was amplified by PCR as described by Juretschko et al. (1998) and sequenced by Sequiserve (Vaterstetten, Germany). For strains MOc-725, MTo-672 and MTo-293, PCR products were cloned first into the pCRII vector (Invitrogen). 16S rRNA genes were restricted into small fragments $(0 \cdot 3-0 \cdot 8 \mathrm{~kb})$ using EcoRI and subcloned into vector pUC18. 16S rRNA gene sequencing was performed by Medigenomix. The sequences of both strands were determined using universal primers for the $\mathrm{pUC18}$ vector.

DNA base composition and DNA-DNA relatedness analysis. The mean mol\% $\mathrm{G}+\mathrm{C}$ content of genomic DNA was measured by the DSMZ. DNA-DNA relatedness was based on relative levels of hybridization to ${ }^{32} \mathrm{P}$-labelled DNA as described previously (Estradade los Santos et al., 2001).

Species-specific PCR primers. Available Burkholderia 16S rRNA gene sequences were aligned to identify regions specific for the novel species; a region corresponding to positions $456-475$ of Escherichia coli (GenBank accession no. V00348) was identified. This region was chosen to define the forward primer $5^{\prime}$-TCCCTGGTCCTAATATG$3^{\prime}$. The reverse primer $\left(5^{\prime}\right.$-CAACCCTCTGTTCCGA- $\left.3^{\prime}\right)$ was identified in a $16 \mathrm{~S}$ rRNA gene region described previously (Pallud et al., 2001). PCR conditions were as follows: initial denaturation for 7 min at $95^{\circ} \mathrm{C}$ followed by 35 cycles of 1 min denaturation at $94{ }^{\circ} \mathrm{C}$, $1 \mathrm{~min}$ annealing at $48^{\circ} \mathrm{C}$ and $1 \mathrm{~min}$ elongation at $72^{\circ} \mathrm{C}$, followed by a final 15 min elongation at $72{ }^{\circ} \mathrm{C}$. 
Table 1. Source and locality of Burkholderia tropica sp. nov. strains analysed

B. tropica strains have been deposited in the ATCC and Collection de l'Institut Pasteur (CIP) with the following numbers: strain MOc-725 (ATCC BAA-567; CIP 107590), strain MTo-672 (ATCC BAA-568; CIP 107591) and strain MTo-293 (ATCC BAA-569; CIP 107592). Climate class codes: 1 , semi-hot subhumid; 2 , semi-hot humid; 3 , hot subhumid; 4 , hot humid; 5 , temperate subhumid. ND, Not determined.

\begin{tabular}{|c|c|c|c|c|c|c|}
\hline Strain & Source & Soil pH & Country & Locality & $\begin{array}{c}\text { Climate } \\
\text { class }\end{array}$ & Reference \\
\hline \multicolumn{7}{|c|}{ ARDRA profile 16} \\
\hline MCh-1057 & Maize rhizoplane & $6 \cdot 76$ & Mexico & Chilpancingo, Guerrero & 1 & This study \\
\hline MCo-7712 & Maize roots ${ }^{\star}$ & $6 \cdot 69$ & Mexico & Coatepec, Veracruz & 2 & This study \\
\hline MOc-725 & Maize rhizoplane & $6 \cdot 35$ & Mexico & Ocotepec, Morelos & 3 & Estrada-de los Santos et al. (2001) \\
\hline MOc-3412 & Maize $\operatorname{roots}^{\star}$ & $6 \cdot 55$ & Mexico & Ocotepec, Morelos & 3 & This study \\
\hline MTe-73523 & Maize roots* & $5 \cdot 04$ & Mexico & Tepoztlan, Morelos & 1 & This study \\
\hline MTe-7363 & Maize rhizoplane & $5 \cdot 04$ & Mexico & Tepoztlan, Morelos & 1 & This study \\
\hline MTl-5681 & Maize roots* & $4 \cdot 56$ & Mexico & Tlayacapan, Morelos & 1 & This study \\
\hline MCo-7931 & Maize rhizosphere & $6 \cdot 89$ & Mexico & Coatepec, Veracruz & 2 & This study \\
\hline $\mathrm{MCu}-831$ & Maize rhizoplane & $7 \cdot 07$ & Mexico & Cuernavaca, Morelos & 1 & This study \\
\hline MMi-786 & Maize rhizoplane & $\mathrm{ND}$ & Mexico & Miacatlán, Morelos & 3 & Estrada-de los Santos et al. (2001) \\
\hline MSj-805 & Maize rhizosphere & $6 \cdot 20$ & Mexico & San J. Atenco, Puebla & 5 & This study \\
\hline MTl-6311 & Maize rhizoplane & $4 \cdot 87$ & Mexico & Tlayacapan, Morelos & 1 & This study \\
\hline MTo-432 & Maize rhizoplane & ND & Mexico & Totontepec, Oaxaca & 2 & Estrada-de los Santos et al. (2001) \\
\hline MTo-672 & Maize stem ${ }^{\star}$ & $\mathrm{ND}$ & Mexico & Totontepec, Oaxaca & 2 & This study \\
\hline MXo-435 & Maize rhizoplane & $7 \cdot 15$ & Mexico & Xoxocotla, Morelos & 3 & This study \\
\hline MXo-437 & Maize rhizosphere & $7 \cdot 15$ & Mexico & Xoxocotla, Morelos & & This study \\
\hline TSj-832 & Teosinte rhizosphere & $6 \cdot 29$ & Mexico & San J. Atenco, Puebla & 5 & This study \\
\hline TTe-1910 & Teosinte stem ${ }^{\star}$ & $7 \cdot 03$ & Mexico & Tepoztlan, Morelos & 1 & This study \\
\hline $\mathrm{MCu}-833$ & Maize roots* & $7 \cdot 07$ & Mexico & Cuernavaca, Morelos & 1 & This study \\
\hline $\mathrm{MCu}-842$ & Maize rhizoplane & $7 \cdot 07$ & Mexico & Cuernavaca, Morelos & 1 & This study \\
\hline MSj-8432 & Maize rhizosphere & $6 \cdot 29$ & Mexico & San J. Atenco, Puebla & 5 & This study \\
\hline MTo-16 & Maize rhizosphere & ND & Mexico & Totontepec, Oaxaca & 2 & Estrada-de los Santos et al. (2001) \\
\hline MTo-293 & Maize stem ${ }^{\star}$ & $\mathrm{ND}$ & Mexico & Totontepec, Oaxaca & 2 & Estrada-de los Santos et al. (2001) \\
\hline \multicolumn{7}{|c|}{ ARDRA profile 19a } \\
\hline LM1-376.8 & Sugarcane roots & $4 \cdot 30$ & South Africa & Tongaat, KwaZulu-Natal & 1 & This study \\
\hline LM2-376.3 & Sugarcane roots & $4 \cdot 98$ & South Africa & Tongaat, KwaZulu-Natal & 1 & This study \\
\hline RASC & Activated sludge & - & USA & Oregon State & - & Suwa et al. (1996) \\
\hline \multicolumn{7}{|l|}{ Not profiled } \\
\hline Ppe5 & Sugarcane stem & ND & Brazil & Pernambuco State & 4 & This study \\
\hline Ppe6 & Sugarcane stem & $\mathrm{ND}$ & Brazil & Pernambuco State & 4 & This study \\
\hline Ppe7 & Sugarcane stem & $\mathrm{ND}$ & Brazil & Pernambuco State & 4 & This study \\
\hline
\end{tabular}

${ }^{\star}$ Surface-sterilized. 


\section{RESULTS AND DISCUSSION}

\section{Growth and phenotypic characteristics of Burkholderia isolates}

$\mathrm{N}_{2}$-fixing Burkholderia isolates analysed in the present work were recovered from the rhizosphere, rhizoplane, roots and stems of maize, teosinte and sugarcane plants grown in different geographical regions from Brazil, Mexico and South Africa with climates ranging from temperate subhumid to hot humid (Table 1). In nitrogen-free LGI-P and BAz enriched semi-solid media, the bacterial growth formed a thin yellowish pellicle approximately $2-4 \mathrm{~mm}$ below the surface. When the bacterial growth was transferred to LGI-P solid medium, small colonies were formed with a yellow centre and white margins. Colonies growing on BAc medium plates were yellowish, round, smooth and convex, 1-2 $\mathrm{mm}$ in diameter, with entire margins after incubation for 4 days as described previously (Estrada-de los Santos et al., 2001). In terms of morphological features, the novel Burkholderia isolates were characterized as rod-shaped $(0.7-0.8 \times 1.5-1.6 \mu \mathrm{m}) \quad$ Gram-negative bacteria. Cells appeared encapsulated, very motile due to the presence of several (one to four) polar flagella (Fig. 1) and possessed peritrichous fimbriae (data not shown). Spores were not observed but poly- $\beta$-hydroxybutyrate granules were viewed under transmission electron microscopy (data not shown). The isolates were oxidase, catalase and urease positive and were able to hydrolyse Tween 80 , but not gelatin or starch. Nitrate was reduced to nitrite, but nitrite was not further

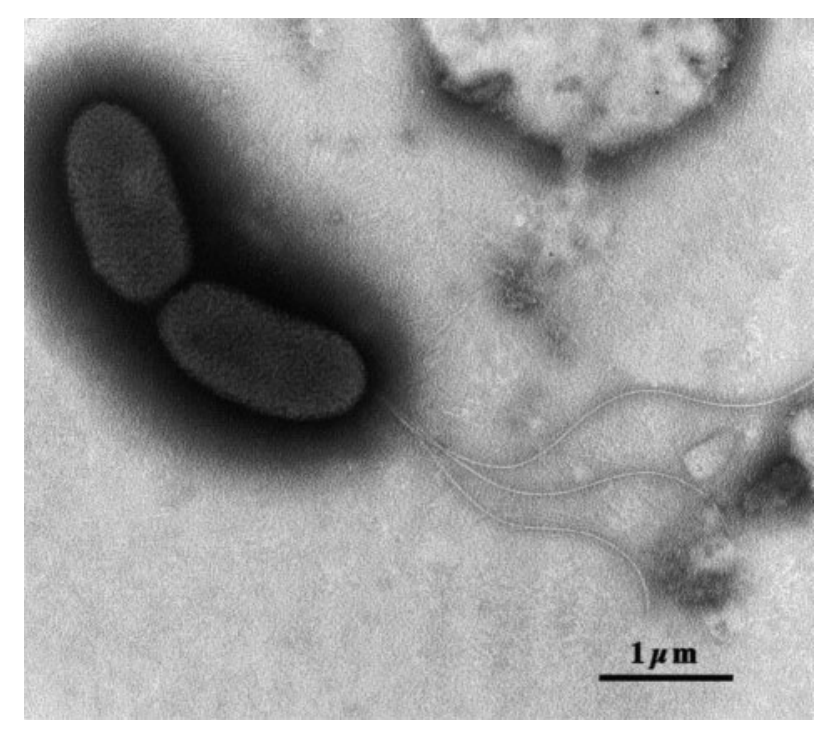

Fig. 1. Transmission electron micrograph of a cell of $B$. tropica sp. nov. strain BM273 showing three polar flagella. Negative staining (aqueous sodium silicotungstate $1 \%$ for $30 \mathrm{~s}$ ). Photo courtesy of René Rohr (University of Lyon 1). Bar, $1 \mu \mathrm{m}$.

reduced. The novel isolates grew and showed nitrogenase activity under microaerobic conditions in nitrogen-free semi-solid JMV, LGI-P and BAz media (Table 2), except for strain RASC. Growth and nitrogenase activity were

Table 2. Comparison of B. tropica sp. nov. with other related Burkholderia species

Species/strains: 1 , B. tropica sp. nov. ( $n=38$, including the type strain); 2, B. sacchari IPT $101^{\mathrm{T}} ; 3$, B. vietnamiensis ( $n=30$, including the type strain); 4, B. kururiensis KP23 ${ }^{\mathrm{T}}$; 5, B. cepacia LMG $1222^{\mathrm{T}}$. +, Good growth; \pm , poor growth; - , no growth; ND, no data available. All species are positive for growth on BSE agar medium at $37^{\circ} \mathrm{C}$ and for oxidase [data for B. sacchari from Brämer et al. (2001) and for B. kururiensis from Zhang et al. (2000)].

\begin{tabular}{|c|c|c|c|c|c|}
\hline Characteristic & 1 & 2 & 3 & 4 & 5 \\
\hline $\begin{array}{l}\mathrm{C}_{2} \mathrm{H}_{2} \text { reduction activity }\left(\mathrm{N}_{2} \text { fixation) in } \mathrm{N} \text {-free }\right. \\
\text { semi-solid LGI-P, JMV and BAz media }\end{array}$ & + & - & + & + & - \\
\hline BAc medium & + & \pm & + & - & + \\
\hline MacConkey medium at $29^{\circ} \mathrm{C}$ & + & - & + & - & + \\
\hline BSE agar medium at $42^{\circ} \mathrm{C}$ & - & - & + & + & + \\
\hline \multicolumn{6}{|l|}{ API $50 \mathrm{CH}$ test: } \\
\hline Urease & $+^{*}$ & - & - & - & - \\
\hline Gelatinase & - & $-{ }^{a} \dagger$ & - & $-{ }^{b}$ & + \\
\hline Nitrate reduced to nitrite & + & $+{ }^{a}$ & + & + & - \\
\hline
\end{tabular}

${ }^{*} B$. tropica strains gave a negative reaction using the Ferguson medium.

$\dagger$ Data taken from: a, Brämer et al. (2001); b, Zhang et al. (2000); c, Yabuuchi et al. (1992). 
stimulated by the addition of yeast extract $\left(100 \mathrm{mg} \mathrm{l}^{-1}\right)$. Optimum temperature for $\mathrm{N}_{2}$-dependent growth was $30^{\circ} \mathrm{C}$, although they still could fix $\mathrm{N}_{2}$ at 25 and $36^{\circ} \mathrm{C}$; growth at $40^{\circ} \mathrm{C}$ was very poor and no growth was observed below $7{ }^{\circ} \mathrm{C}$ or above $42^{\circ} \mathrm{C}$. Similarly, all of the isolates grew on BSE agar medium at $37^{\circ} \mathrm{C}$ but not at $42^{\circ} \mathrm{C}$. The novel isolates grew well at $\mathrm{pH}$ values between 4.5 and $6 \cdot 5$, but poor growth was observed at $\mathrm{pH} 7 \cdot 0-7 \cdot 5$; optimal growth was observed between pH $5 \cdot 0$ and $5 \cdot 8$. While strains of B. tropica sp. nov. were found in the rhizosphere and associated with plants growing in soils with a $\mathrm{pH}$ in the range $4 \cdot 5-7 \cdot 1$, isolation from maize plants cultivated on soils with a $\mathrm{pH}$ higher than $7 \cdot 5$ was unsuccessful. This result is in accordance with the good growth of the novel isolates on culture media with a $\mathrm{pH} 4 \cdot 5-6 \cdot 5$. Bacteria of the genus Burkholderia are considered to be characteristic of neutral $\mathrm{pH}$ environments (Liesack et al., 1997), but recent evidence suggests a high abundance of Burkholderia in acidic soils (Nogales et al., 2001).

Although the expression of $\mathrm{N}_{2}$-fixing genes in an endosymbiotic Burkholderia species has been observed (Minerdi et al., 2001), among the hitherto-described species of the genus Burkholderia, $\mathrm{N}_{2}$-fixing ability has only been found in B. vietnamiensis (Gillis et al., 1995) and Burkholderia kururiensis (Estrada-de los Santos et al., 2001). In addition, the presence of the nifH gene encoding dinitrogenase reductase, a key enzyme in $\mathrm{N}_{2}$ fixation, has been detected (Moulin et al., 2001) in the recently described nodulating species B. tuberum (Vandamme et al., 2002). In the present study, diazotrophic Burkholderia isolates recovered from plants grown in Brazil, Mexico and South Africa shared a high similarity in their phenotypic and genomic traits, but exhibited little resemblance to other Burkholderia species. Phenotypic characteristics for the differentiation of B. tropica sp. nov. from other $\mathrm{N}_{2}$-fixing Burkholderia species as well as from related Burkholderia species are shown in Table 2. Differences in the usage of carbon sources by the novel isolates and other related Burkholderia species according to the API 50CH test are shown in Table 3. According to the Biolog carbon source utilization tests, a broad spectrum of sugars and alcohols were used (see supplementary data in IJSEM Online).

\section{SDS-PAGE of whole-cell proteins and siderophore production}

Whole-cell protein extracts were prepared from 38 strains of B. tropica sp. nov. and from several related species. Strains isolated from maize, teosinte and sugarcane plants growing in different regions of Brazil, Mexico and South Africa showed almost identical protein patterns (Fig. 2). These protein patterns were clearly different from other $\mathrm{N}_{2}$-fixing and from non- $\mathrm{N}_{2}$-fixing Burkholderia species. All of the isolates corresponding to ARDRA genotypes 16, 17 and 19 showed the ability to produce siderophores. Ninety-two per cent of the strains produced hydroxamates as the main type of siderophore.
Table 3. Discriminatory carbon source assimilation of $B$. tropica sp. nov. compared with other related Burkholderia species based on the API $50 \mathrm{CH}$ system

Species/strains: 1 , B. tropica sp. nov. $(n=38) ; 2$, B. sacchari IPT $101^{\mathrm{T}}$; 3, B. cepacia LMG $1222^{\mathrm{T}}$; 4, B. vietnamiensis $\mathrm{TVV}^{\mathrm{T}}{ }^{\mathrm{T}}$; 5 , B. kururiensis $\mathrm{KP} 23^{\mathrm{T}} ; 6, B$. caribensis MWAP64 ${ }^{\mathrm{T}}$. All of the $B$. tropica strains assimilated the following substrates: $\mathrm{N}$-acetylglucosamine, DL-arabinose, D-arabitol, D-fructose, galactose, gluconate, D-glucose, glycerol, inositol, 2-ketogluconate, malate, mannitol, D-mannose, phenylacetate, sorbitol and D-xylose. None of the B. tropica strains assimilated erythritol, glycogen, inulin, melezitose, melibiose, methyl $\alpha$-glucoside, methyl $\alpha$-D-mannoside, methyl $\beta$-xyloside, L-sorbose, starch or D-turanose. B. tropica strains: +, $>95 \%$ of strains gave a positive reaction;,$->95 \%$ of strains gave a negative reaction; $\mathrm{V}+, 55-70 \%$ of strains gave a positive reaction.

\begin{tabular}{|lcccccc|}
\hline Substrate & $\mathbf{1}$ & $\mathbf{2}$ & $\mathbf{3}$ & $\mathbf{4}$ & $\mathbf{5}$ & $\mathbf{6}$ \\
\hline Adonitol & + & + & + & - & + & + \\
Cellobiose & + & - & + & + & - & + \\
D-Fucose & + & + & - & + & + & - \\
L-Fucose & + & + & + & - & + & + \\
$\beta$-Gentiobiose & + & - & + & + & - & - \\
Rhamnose & + & - & - & - & + & + \\
Ribose & + & - & + & + & + & + \\
Lactose & $\mathrm{V}$ & - & - & - & - & - \\
D-Lyxose & $\mathrm{V}$ & + & + & + & + & - \\
Salicin & $\mathrm{V}$ & - & + & + & - & - \\
Trehalose & $\mathrm{V}$ & - & + & + & - & - \\
Amygdalin & - & - & + & + & - & - \\
L-Arabitol & - & - & + & - & + & + \\
Arbutin & - & - & + & - & - & - \\
Dulcitol & - & - & + & + & - & - \\
5-Ketogluconate & - & - & + & - & + & - \\
Maltose & - & - & - & - & - & + \\
D-Raffinose & - & + & + & + & - & - \\
Sucrose & - & + & + & + & - & - \\
D-Tagatose & - & - & + & + & - & - \\
Xylitol & - & - & + & - & + & + \\
L-Xylose & - & - & - & - & + & - \\
& & & & & & \\
\hline
\end{tabular}

\section{ARDRA and phylogenetic 16S rRNA gene analysis}

A group of $\mathrm{N}_{2}$-fixing Burkholderia isolates, designated ARDRA genotypes 16,17 and 19, was described previously (Estrada-de los Santos et al., 2001). These genotypes showed identical ARDRA profiles with enzymes AluI, DdeI, HaeIII, HhaI, MspI and RsaI, but could be distinguished by the enzyme HinfI (see Supplementary Fig. A in IJSEM Online). Strain $\mathrm{Ppe} 8^{\mathrm{T}}$ showed an ARDRA profile identical to genotype 19. Strains LM1-376.8, LM2-376.3 and RASC showed the same profiles as genotype 19 except with HaeIII, and therefore they were designated ARDRA genotype 19a (Table 1). When the 16S rRNA gene was restricted with each of the seven different enzymes, the sum of the fragments was approximately $1.5 \mathrm{~kb}$, except in the case of strains 


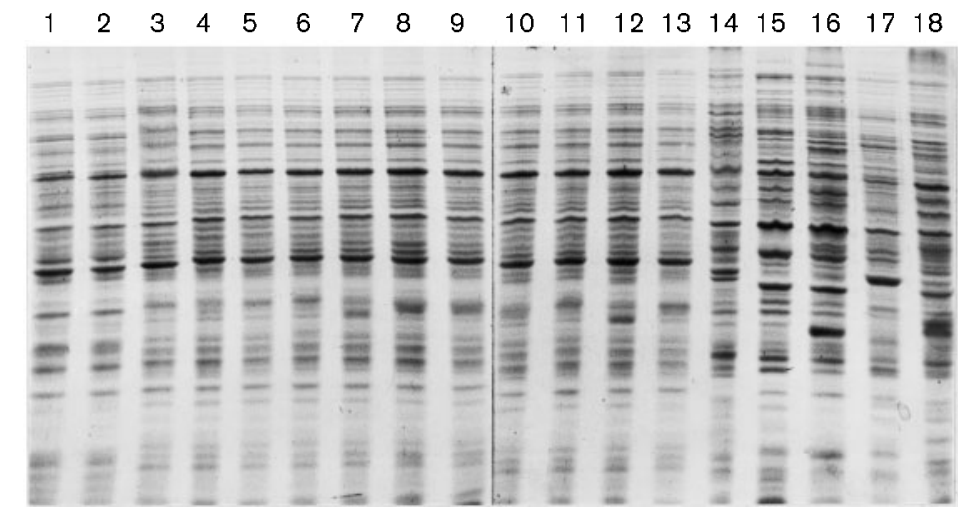

Fig. 2. SDS-PAGE of selected B. tropica sp. nov. strains and Burkholderia reference strains. Lanes: $1-13, B$. tropica strains MOc-725, TTe-225, MTe-73523, MTo-293, LM1-376.8, LM2-376.3, MTo-672, TTe-1910, MXo-435, MCh-1057, TSj-832, MSj-8432 and $P$ pe $8^{\top}$ respectively; $14, B$. vietnamiensis $\mathrm{TVV}^{\mathrm{T}}$; $15, B$. kururiensis $\mathrm{KP}_{2} 3^{\mathrm{T}}$; 16 , ' $B$. brasilensis' M130; 17, $B$. caribensis MWAP64 $4^{\top} ; 18$, B. cepacia LMG $1222^{\top}$.

corresponding to ARDRA genotype 17, which were greater than $2.0 \mathrm{~kb}$ with the HinfI enzyme (see Supplementary Fig. A, lane 8, in IJSEM Online). A possible explanation for the larger size could be the amplification of distinct copies of these genes, some of which lack one of the restriction sites. It is known that bacteria have up to 15 copies of ribosomal operons and that they have internal differences (Klappenbach et al., 2000).

The 16S rRNA gene sequence of strain $\mathrm{Ppe} 8^{\mathrm{T}}$ as well as sequences for isolates MOc-725, MTo-672, MTo-293 and LM2-376.3, representing different ARDRA genotypes, were compared with available 16S rRNA gene sequences from all of the Burkholderia species. The phylogenetic tree shown in Fig. 3 illustrates the position of the novel isolate group, B. tropica sp. nov., relative to other Burkholderia species. Strains Ppe $8^{\mathrm{T}}$, MTo-293, LM2-376.3, MOc-725 and MTo672 were closely related, forming a cluster with strains BM16 and BM273 described in a previous study (Estrada et al., 2002), as well as with strain AB98 (Cruz et al., 2001). The similarity among the 16S rRNA gene sequences of these strains ranged from $99 \cdot 2$ to $99 \cdot 9 \%$. The $\mathrm{N}_{2}$-fixing species B. tropica clearly constituted a well-supported cluster separate from the cluster formed by the diazotrophic species B. kururiensis/B. tuberum. Burkholderia sacchari, a nondiazotrophic bacterium, was the closest species to the B. tropica cluster $\left(97 \cdot 2 \%\right.$ similarity). The $\mathrm{N}_{2}$-fixing species B. vietnamiensis, which belongs to the second major lineage of Burkholderia comprising the 'Burkholderia cepacia complex' (Vandamme et al., 1997), appeared distantly related to B. tropica with a sequence similarity of $<96 \%$ (Supplementary Fig. B). Since $97 \%$ is the threshold $16 \mathrm{~S}$ rRNA gene similarity level for the delineation of bacterial species (Stackebrandt \& Goebel, 1994), B. tropica could be clearly differentiated from the closely related species B. sacchari and B. tuberum ( $96 \cdot 2 \%$ similarity).

\section{DNA-DNA relatedness analysis}

Strains MOc-725 (genotype 16), MTo-672 (genotype 17) and MTo-293 (genotype 19), as well as strains LM1-376.8, LM2-376.3 and RASC (genotype 19a), were related to strain $\mathrm{Ppe} 8{ }^{\mathrm{T}}$ with DNA-DNA reassociation values of $74-97 \cdot 3 \%$. Type strains of closely related Burkholderia species such as
B. sacchari, B. tuberum, B. phymatum, B. kururiensis, B. cepacia, Burkholderia graminis and Burkholderia caribensis exhibited low DNA-DNA reassociation levels, ranging from 41 to $9 \cdot 8 \%$, with strain $\mathrm{Ppe} 8^{\mathrm{T}}$.

\section{Species-specific PCR}

Results showed that PCR amplification was strictly specific for B. tropica strains. An $800 \mathrm{nt}$ amplicon was obtained with B. tropica strains (Ppe8 ${ }^{\mathrm{T}}$, SMi-583, MMi-786, MTo-431, BM16, BM273, MTo-293, LM1-376.8 and LM2-376.3) but not with type strains of other related Burkholderia species such as Burkholderia caledonica, B. caribensis, B. cepacia, Burkholderia fungorum, B. graminis, Burkholderia phenazinium, Burkholderia thailandensis and B. vietnamiensis, nor with six strains of Burkholderia cenocepacia (data not shown).

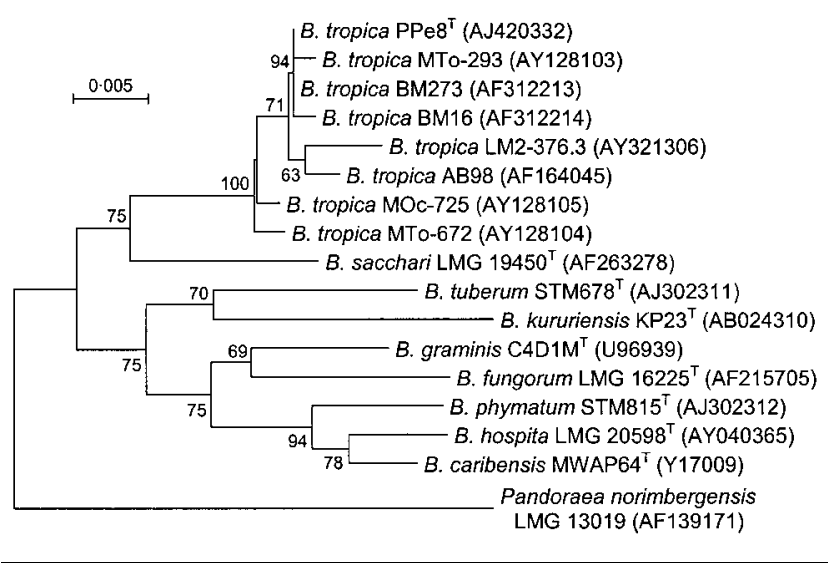

Fig. 3. Phylogenetic tree based on $16 \mathrm{~S}$ rRNA gene sequences showing the relatedness among $B$. tropica sp. nov. and the nearest Burkholderia species. Phylogenetic relationships were estimated according to Jukes \& Cantor (1969) and the tree was constructed by the neighbour-joining method (Saitou \& Nei, 1987). The alignment included 1349 nt. Bootstrap probabilities (Kumar et al., 1993) are indicated at the branch points. The bar represents $5 \mathrm{nt}$ substitutions per 1000 nt. The GenBank accession number for each strain is shown in parentheses. 


\section{Taxonomic considerations}

Many phenotypic features and all of the genomic characteristics described above agree with similarity criteria recommended for the delineation of bacterial species (Vandamme et al., 1996). Accordingly, we consider that the strains analysed in this work belong to a novel plantassociated $\mathrm{N}_{2}$-fixing bacterial species within the genus Burkholderia and propose the name Burkholderia tropica sp. nov.

\section{Description of Burkholderia tropica sp. nov.}

Burkholderia tropica (L. fem. adj. tropica tropical).

Cells are slightly curved rods, approximately $1.5-1.6 \mu \mathrm{m}$ long and $0 \cdot 7-0 \cdot 8 \mu \mathrm{m}$ wide. They occur singly and possess a capsule. They are motile by means of one to four polar flagella. Isolates are Gram negative and oxidase and catalase positive. On LGI-P solid medium, small colonies are formed with a yellow centre and white margins. Colonies on BAc plates are yellowish, round, smooth and convex with entire margins. Growth and acetylene reduction to ethylene are observed in nitrogen-free semi-solid media. Strains have an aerobic metabolism but fix nitrogen microaerobically. They grow well with ammonium, and nitrate is reduced to nitrite, but nitrite is not further reduced. Nitrate and ammonium inhibit $\mathrm{N}_{2}$ fixation, but small amounts of yeast extract (100 $\mathrm{mg} \mathrm{l}^{-1}$ ) enhance $\mathrm{N}_{2}$ fixation. Several carbon sources support growth, including sugars and organic acids. Growth occurs from 22 to $40{ }^{\circ} \mathrm{C}$ and the optimum temperature is $30^{\circ} \mathrm{C}$. No hydrolysis of starch or gelatin is observed, but Tween 40 and Tween 80 are hydrolysed. Characteristics that differentiate B. tropica from other $\mathrm{N}_{2}$-fixing Burkholderia species are listed in Tables 2 and 3. B. tropica can also be differentiated from other $\mathrm{N}_{2}$-fixing and non- $\mathrm{N}_{2}$-fixing Burkholderia species by $16 \mathrm{~S}$ rRNA gene PCR primers. The species B. tropica comprises four different ARDRA genotypes. It has a $\mathrm{G}+\mathrm{C}$ content of $63.5 \mathrm{~mol} \%$.

The type strain is strain $\mathrm{Ppe}^{\mathrm{T}}$ ( $=$ ATCC BAA $-831^{\mathrm{T}}=\mathrm{LMG}$ $22274^{\mathrm{T}}=$ DSM $15359^{\mathrm{T}}$ ), isolated from sugarcane var. SP 711406 grown in the fields of the Cruangi Sugar factory located in Pernambuco State, Brazil.

\section{ACKNOWLEDGEMENTS}

This study is dedicated to J. Döbereiner, in memoriam. This work was funded in part by Pronex II/CNPq (grant 661309/97-5), which supported the Brazilian partnership, and Conselho Nacional de Pesquisa e Desenvolvimento ( $\mathrm{CNPq}$ )-Brazil for a $\mathrm{PhD}$ fellowship. Thanks also are due to the German Brazilian Scientific \& Technological co-operation (grant BRA ENV 57) by the BMBF-Berlin and CNPqBrazil. This research was also partially funded by Consejo Nacional de Ciencia y Tecnología (CONACyT)-México (grant 33576-V) and by grants from BGR (Bureau des Ressources Génétiques) and PICS 1061 from CNRS-France. We thank Dr M. Dunn for constructive English corrections, as well as G. Paredes-Valdez and L. Martínez-Aguilar for technical assistance. We are indebted to Pr. R. Rohr (University of Lyon 1) for electron microscopy and J. H. Omarjee for $16 \mathrm{~S}$ rRNA gene sequences of South African strains LM1-376.8 and LM2-376.3. We also acknowledge the help of I. Caballero-Mellado (Instituto Nacional de Estadística, Geografía e Informática, México) for detailed information on climate class, and M. Carcaño, J. Leyva and A. Morett for plant collection. Thanks are also due to CONACyT and to Dirección General de Estudios de Posgrado (DGEP)-UNAM for a PhD fellowship to P. E.-de los S.

\section{REFERENCES}

Ausubel, F. M., Brent, R., Kingston, R. E., More, D. D., Seidman, J. G., Smith, J. A. \& Struhl, K. (1987). Current Protocols in Molecular Microbiology. New York: Wiley.

Brämer, C. O., Vandamme, P., da Silva, L. F., Gomez, J. G. C. \& Steinbüchel, A. (2001). Burkholderia sacchari sp. nov., a polyhydroxyalkanoate-accumulating bacterium isolated from soil of a sugar-cane plantation in Brazil. Int J Syst Evol Microbiol 51, 1709-1713.

Burbage, D. A. \& Sasser, M. (1982). A medium selective for Pseudomonas cepacia. Phytopathology 76, 706.

Burris, R. H. (1972). Nitrogen fixation assay - methods and techniques. Methods Enzymol 24B, 415-431.

Coenye, T. \& Vandamme, P. (2003). Diversity and significance of Burkholderia species occupying diverse ecological niches. Environ Microbiol 5, 719-729.

Cruz, L. M., Maltempi-de Souza, E., Weber, O. B., Baldani, J. I., Döbereiner, J. \& Pedrosa, O. (2001). $16 \mathrm{~S}$ ribosomal DNA characterization of nitrogen-fixing bacteria isolated from banana (Musa spp.) and pineapple (Ananas comosus (L.) Merril). Appl Environ Microbiol 67, 2375-2379.

Czàky, T. Z. (1948). On the estimation of bound hydroxylamine in biological materials. Acta Chem Scand 2, 450-454.

Estrada-de los Santos, P., Bustillos-Cristales, R. \& CaballeroMellado, J. (2001). Burkholderia, a genus rich in plant-associated nitrogen fixers with wide environmental and geographic distribution. Appl Environ Microbiol 67, 2790-2798.

Estrada, P., Mavingui, P., Cournoyer, B., Fontaine, F., Balandreau, J. \& Caballero-Mellado, J. (2002). A $\mathrm{N}_{2}$-fixing endophytic Burkholderia sp. associated with maize plants cultivated in Mexico. Can J Microbiol 48, 285-294.

Gillis, M., Trân Van, V., Bardin, R. \& 7 other authors (1995). Polyphasic taxonomy in the genus Burkholderia leading to an emended description of the genus and proposition of Burkholderia vietnamiensis sp. nov. for $\mathrm{N}_{2}$-fixing isolates from rice in Vietnam. Int J Syst Bacteriol 45, 274-289.

Hartmann, A., Baldani, J. I., Kirchhof, G., Assmus, B., Hutzler, P., Springer, N., Ludwig, G. W., Baldani, V. L. \& Döbereiner, J. (1995). Taxonomic and ecological studies of diazotrophic rhizosphere bacteria using phylogenetic probes. In Azospirillum VI and Related Microorganisms: Genetics, Physiology and Ecology, pp. 416-427. Edited by I. Fendrick, M. del Gallo, J. Vanderleyden \& M. Zamaroczy. Berlin: Springer.

Henry, D. A., Campbell, M. E., LiPuma, J. J. \& Speert, D. P. (1997). Identification of Burkholderia cepacia isolates from patients with cystic fibrosis and use of a simple new selective medium. J Clin Microbiol 35, 614-619.

Jukes, T. H. \& Cantor, C. R. (1969). Evolution of protein molecules. In Mammalian Protein Metabolism, pp. 21-132. Edited by H. N. Munro. New York: Academic Press.

Juretschko, S., Timmermann, G., Schmid, M., Schleifer, K.-H., Pommerening-Röser, A., Koops, H. P. \& Wagner, M. (1998). Combined molecular and conventional analyses of nitrifying 
bacterium diversity in activated sludge: Nitrosococcus mobilis and Nitrospira-like bacteria as dominant populations. Appl Environ Microbiol 64, 3042-3051.

Kirchhof, G., Schloter, M. Aßmus B. \& Hartmann, A. (1997). Molecular microbial ecology approaches applied to diazotrophs associated with non-legumes. Soil Biol Biochem 29, 853-862.

Klappenbach, J. A., Dunbar, J. M. \& Schmidt, T. M. (2000). rRNA operon copy number reflects ecological strategies of bacteria. Appl Environ Microbiol 66, 1328-1333.

Kumar, S., Tamura, K. \& Nei, M. (1993). MEGA: molecular evolutionary genetics analysis, version 1.0. University Park, PA: The Pennsylvania State University.

Liesack, W., Janssen, P. H., Rainey, F. A., Ward-Rainey, N. L. \& Stackebrandt, E. (1997). Microbial diversity in soil: the need for a combined approach using molecular and cultivation techniques. In Modern Soil Microbiology, pp. 375-439. Edited by J. D. Van Elsas, J. T. Trevors \& E. M. H. Wellington. New York: Marcel Dekker.

Minerdi, D., Fani, R., Gallo, R., Boarino, A. \& Bonfante, P. (2001). Nitrogen fixation genes in an endosymbiotic Burkholderia strain. Appl Environ Microbiol 67, 725-732.

Moulin, L., Munive, A., Dreyfus, B. \& Boivin-Masson, C. (2001). Nodulation of legumes by members of the beta-subclass of Proteobacteria. Nature 411, 948-950.

Nogales, B., Moore, E. R. B., Llobet-Brossa, E., Rossello-Mora, R., Amman, R. \& Timmis, K. N. (2001). Combined use of $16 \mathrm{~S}$ ribosomal DNA and $16 \mathrm{~S}$ rRNA to study the bacterial community of polychlorinated biphenyl-polluted soil. Appl Environ Microbiol 67, 1874-1884.

Pallud, C., Viallard, V., Balandreau, J., Normand, P. \& Grundmann, G. (2001). Combined use of a specific probe and PCAT medium to study Burkholderia in soil. J Microbiol Methods 47, 25-34.

Reis, V. M., Olivares, F. L. \& Döbereiner, J. (1994). Improved methodology for isolation of Acetobacter diazotrophicus and confirmation of its endophytic habitat. World J Microbiol Biotechnol 10, 101-104.

Saitou, N. \& Nei, M. (1987). The neighbor-joining method: a new method for reconstructing phylogenetic trees. Mol Biol Evol 4, 406-425.

Schwyn, B. \& Neilands, J. B. (1987). Universal chemical assay for detection and determination of siderophores. Anal Biochem 160, $47-56$.

Smibert, R. M. \& Krieg, N. R. (1981). General characterization. In Manual of Methods for General Bacteriology, pp. 409-443. Edited by P. Gerhardt, R. G. E. Murray, R. N. Costillo, E. W. Nester,
W. A. Wood, N. R. Krieg \& G. B. Phillips. Washington, DC: American Society for Microbiology.

Stackebrandt, E. \& Goebel, B. M. (1994). Taxonomic note: a place for DNA-DNA reassociation and 16S rRNA sequence analysis in the present species definition in bacteriology. Int J Syst Bacteriol 44, 846-849.

Suwa, Y., Wright, A. D., Fukimori, F., Nummy, K. A., Hausinger, R. P., Holben, W. E. \& Forney, L. J. (1996). Characterization of a chromosomally encoded 2,4-dichlorophenoxiacetic acid/ $\alpha$-ketoglutarate dioxygenase from Burkholderia sp. strain RASC. Appl Environ Microbiol 62, 2464-2469.

Trân Van, V., Mavingui, P., Berge, O., Balandreau, J. \& Heulin, T. (1994). Promotion de croissance du riz inoculé par une bactérie fixatrice d'azote, Burkholderia vietnamiensis, isolée d'un sol sulfaté acide du Viêt-nam. Agronomie 14, 697-707 (in French).

Vandamme, P., Pot, B., Gillis, M., de Vos, P., Kersters, K. \& Swings, J. (1996). Polyphasic taxonomy, a consensus approach to bacterial systematics. Microbiol Rev 60, 407-438.

Vandamme, P., Holmes, B., Vancanneyt, M. \& 8 other authors (1997). Occurrence of multiple genomovars of Burkholderia cepacia in cystic fibrosis patients and proposal of Burkholderia multivorans sp. nov. Int J Syst Bacteriol 47, 1188-1200.

Vandamme, P., Goris, J., Chen, W.-M., de Vos, P. \& Willems, A. (2002). Burkholderia tuberum sp. nov. and Burkholderia phymatum sp. nov., nodulate the roots of tropical legumes. Syst Appl Microbiol 25, 507-512.

Weber, O. B., Baldani, V. L. D., Teixeira, K. R. S., Kirchhof, G., Baldani, J. I. \& Döbereiner, J. (1999). Isolation and characterization of diazotrophic bacteria from banana and pineapple plants. Plant Soil 210, 103-113.

Weisburg, W. G., Barns, S. M., Pelletier, D. A. \& Lane, D. J. (1991). $16 \mathrm{~S}$ ribosomal DNA amplification for phylogenetic study. J Bacteriol 173, 697-703.

Yabuuchi, E., Kosako, Y., Oyaizu, H., Yano, I., Hotta, H., Hashimoto, Y., Ezaki, T. \& Arakawa, M. (1992). Proposal of Burkholderia gen. nov. and transfer of seven species of the genus Pseudomonas homology group II to the new genus, with the type species Burkholderia cepacia (Palleroni and Holmes 1981) comb. nov. Microbiol Immunol 36, 1251-1275.

Zhang, H., Hanada, S., Shigematsu, T., Shibuya, K., Kamagata, Y., Kanagawa, T. \& Kurane, R. (2000). Burkholderia kururiensis sp. nov., a trichloroethylene (TCE)-degrading bacterium isolated from an aquifer polluted with TCE. Int J Syst Evol Microbiol 50, 743-749. 